\title{
Deposit modeling for archaeological projects: methods, practice and future developments
}

Chris Carey ${ }^{1}$, Andy J. Howard ${ }^{2,3}$, Jane Corcoran ${ }^{4}$, David Knight ${ }^{5}$, Jen Heathcote ${ }^{6}$

${ }^{1}$ School of Environment and Technology, University of Brighton, Lewes Road, Brighton, BN2 4GJ, United Kingdom

${ }^{2}$ Landscape Research \& Management, Stanmore, Bridgnorth, WV15 5JG, United Kingdom

${ }^{3}$ Department of Archaeology, University of Durham, South Road, Durham, DH1 3LE, United Kingdom

${ }^{4}$ Jane Corcoran, Historic England, 195-205 High Street, Eastgate Court, Guildford, GU1 3EH, United Kingdom

${ }^{5}$ David Knight, Trent \& Peak Archaeology, York Archaeological Trust, 47 Aldwark, York, YO1 7BX, United Kingdom

6 Jen Heathcote, Historic England, The Engine House, Fire Fly Avenue, Swindon, SN2 2EH, United Kingdom

\begin{abstract}
This paper considers the application of deposit modeling within archaeological projects, summarizing the results of a Historic England funded project aimed at developing 'good practice' for the application of these techniques within terrestrial environments. It provides an overview of what deposit modeling is, the environments where it can be used and the methods most commonly employed. The paper identifies a series of issues and challenges in using deposit models within archaeological investigations, such as the archiving of geotechnical data, the testing of deposit models against the distribution of archaeological sites and features, and integrating sediment stratigraphies derived from deposit modeling with post-excavation records. We argue that deposit modeling is a valuable tool for archaeologists to employ and can be used to design appropriate excavation strategies to target sites and features, thereby increasing the information yield of a
\end{abstract}


project. In this sense deposit modeling can be used as a framework for archaeological projects that are investigating sediment sequences in complex geomorphological environments, starting with preevaluation data gathering, through to focusing excavation strategies, and within post-excavation analysis. Whilst this paper is focused upon the terrestrial archaeological record, the themes discussed have resonance for archaeological records across the globe, including the offshore zone.

KEY WORDS deposit modeling, geoarchaeology, sediment stratigraphy, archaeological mitigation

\section{Introduction}

Deposit modeling is a term that is familiar to both archaeologists and geoarchaeologists alike, however, what deposit modeling actually is within an archaeological project and which techniques and methods are suitable, as well as data requirements, have witnessed little debate both within the practitioner and research communities (Carey et al. 2018). This is a curious situation, given that most archaeological remains (sites, features and artefacts) are stratified within and beneath sedimentary deposits that have accumulated through a combination of anthropogenic and natural processes (Barker, 1993, Price et al., 2011;). The deposition of these sediment contexts can occur over a range of timescales and across numerous geomorphic terrains (aeolian, colluvial, alluvial), often resulting in highly complex, deeply stratified sequences (e.g. Howard et al., 2003, and papers therein, Schott 2017). Therefore, understanding the spatial distribution and preservation potential of archaeological remains requires knowledge of the 3-dimensional geoarchaeological sediment architecture of sites, which can only be visualized and achieved through some form of deposit modeling.

From an archaeological perspective, deposit modeling is one of the more commonly utilized methodological approaches undertaken by geoarchaeologists. These approaches have been 
developed for archaeological applications, but derive from the principles of stratigraphic analysis developed in the geological sciences by pioneers such as William Smith (1769-1839), and are now utilized at much larger scales in the oil and gas industries (e.g. Nwankwo, et al. 2014), although refined for modeling of sediment bodies deposited within the Quaternary (e.g. Brown et al. 2015). In archaeological projects, the application of deposit modeling has been utilized within terrestrial (e.g. Champness 2018), intertidal (e.g. Krawiec 2018) and marine environments (e.g. Bicket and Tizzard, 2015). Within a UK context the application of deposit modeling is increasing, especially associated with developer-funded archaeological projects (see Burton et al., 2011, Carey et al., 2017; Carey et al., 2018 and articles therein). Likewise, there are multiple examples of deposit models published internationally often to provide the wider landscape context of significant archaeological sites (e.g. Pastre et al,. 2014, Ames \& Cordova, 2015, Ayala et al., 2017), or to advance aspects of heritage management (Amato et al., 2018; Mozzi et al., 2018), although they can be referred to as landscape evolution models or geological models, rather than deposit models per se. Given this increasing application of geoarchaeological deposit modeling within archaeology, either for research driven projects or as part of mitigation and heritage management frameworks, it is timely to review what deposit modeling is, the practices and methods being utilized, the challenges ahead and to consider what is 'good practice' and to promote the development of this technique.

The themes explored in this paper derive from a Historic England funded project entitled 'Deposit Modeling for Archaeological Projects', which sought to bring together an invited group of modeling practitioners and other key stakeholders with a vested interest in the methodologies, for example, archaeological consultants and heritage managers; to this end, a workshop was held in London in the summer of 2016. The workshop sought the views, experiences and methodologies used by invited delegates with the data captured through a series of presentations and roundtable discussions. Points raised in the discussions are synthesized here but it is not the intention of this paper to focus on individual sites and detail of their methodologies since these aspects are covered by the technical monograph edited as part of the project (Carey et al., 2018); rather this paper aims 
to horizon-scan to bring deposit modeling to the fore in order to promote discussion regarding its application and consider the challenges ahead. Furthermore, with funding from Historic England and the remit of the project, the focus of the workshop was unavoidably focused on England and deposit modeling practices in terrestrial environs. However, the issues, principles and experiences described here have generic relevance for archaeologists seeking to apply deposit modeling methodologies across the globe, including offshore submerged landscapes.

At the outset of this paper, it is worth considering that whilst it may not be obvious, geoarchaeologists and archaeologists take different, but complimentary approaches to site investigation. At a broad level geoarchaeologists study the formation of sediments, landscape evolution and the role of anthropogenic and natural drivers of environmental change (Howard and Macklin, 1999, Canti et al., 2015), whereas archaeologists study sites, features and artefacts to elucidate the dynamics of past societies. Part of the reason for the limited application of deposit modeling within archaeological projects is likely to be at least partly a function of this divide and the contrast between the approach of the arts and the sciences to the study of the record, and the scales at which geoarchaeologists and archaeologists investigate; with the exception of micromorphologists, the former tend to work at the meso- and macro-scale (i.e. landscape evolution and drivers of environmental change) whereas the latter work typically work at a smaller scale, including the microscale (i.e. site-, to feature-, to context-scale). It is inescapable that any archaeologists during an excavation must recover artefacts from within a sediment unit (Renfew, 1976), whether this is anthropogenically derived (e.g. a fill or a deposit) or naturally deposited (e.g. alluvium). This difference in the scales and types of approaches has previously led to some difficulties in stitching together these two ends of the archaeological spectrum, an issue explored further below. Furthermore, deposit modeling is a process that can inform the interpretation of excavated deposits and from the outset provides a framework for site investigation strategies, particularly in environments that have deep vertical or laterally accreted sediments $(>1 \mathrm{~m})$ of Holocene and Pleistocene age (Sidell et al., 2000, Passmore et al., 2006, Carey et al., 2017). 


\section{Deposit modeling: a definition}

Deposit modeling is not a new technique and builds upon well-established techniques used by the wider geological science community. Within the Historic Environment sector, it has been applied to further understand archaeological records within a variety of terrestrial environments including peatlands (Chapman \& Gearey ,2013), river valleys (Bates \& Bates, 2000, Brown et al., 2005, Bates \& Stafford, 2013) and urban settings (Neal, 2014, Amato et al., 2018, Mozzi et al., 2018), although in some investigations the analysis and visualization of sedimentary sequences is not directly referred to as an archaeological deposit model. They also form a staple part of the corpus of data produced by marine archaeologists during the investigations of now submerged landscapes both in northern Europe (e.g. Bicket and Tizzard, 2015) and more globally (Bailey et al., 2015). Whether on land or beneath the sea, the principle aim of these models is to characterize sub-surface sediment stratigraphy in order to understand geomorphological landscape evolution and to elucidate archaeological sites and their records. From a heritage management perspective, this allows an inference to be made about archaeological potential based on a sound knowledge of the sub-surface topography and sediment architecture, depositional environments and patterns of erosion and sedimentation.

From this viewpoint deposit modeling must make a prediction of the sub-surface environment using more than one piece of data or single data point (Figure 1). For example, deposit models will commonly model a sediment unit or bounding surface using multiple data points derived from borehole logs or geophysical data. These data points provide a discontinuous spread of information across a given study area, but can be correlated and extrapolated so that key sediment units or surfaces can be interpolated from the known points. Whilst such an approach has applicability in a variety of depositional environments, it is most commonly applied in situations where thick $(>1 \mathrm{~m})$ sediment sequences have formed (see Carey et al. 2018). 
Geoarchaeological deposit models in both terrestrial and marine environments can range in application and complexity. They can be as simple as identifying areas of a site with different sediment characteristics or determining the relationship between two stratified deposit sequences. At the opposite end of the spectrum, complex deposit models have been developed, utilizing purposive boreholes, sometimes coupled with airborne and/or terrestrial remote sensing technologies to identify patterns of sedimentation, landform evolution, paleo-landsurfaces, where cultural or environmental archaeological remains may be preferentially preserved, for example within and at the margins of paleochannels, within or upon buried gravel islands and elevated terrace surfaces (e.g. Carey and Knight 2018). However, whilst geoarchaeological deposit models are inherently grounded in conventional archaeological approaches (primarily understanding stratigraphy), their full potential has yet to be realized in either commercial or research spheres. Importantly, terrestrial deposit models are often seen as additional to an archaeological project, rather than the underlying framework through which to design evaluation and mitigation strategies and decision making. This observation, drawn for terrestrial environments, is in contrast to the marine environment where mapping key landform assemblages and the internal stratigraphy and hence cultural and environmental potential provide the starting point for any subsequent archaeological investigations (Cowrie, 2011), due to the inherent difficulty in accessing these sediment sequences and their associated archaeological records.

\section{Where should a deposit model be constructed within the archaeological process?}

Deposit modeling provides an understanding of site stratigraphy and landscape evolution, and in turn, allows an assessment of the probable distribution and preservation potential of archaeological remains before costly and intrusive excavations take place. Such knowledge is an essential prerequisite to any project design, informing the scale and type of resources needed; therefore, it has the potential to reduce overall financial costs, both to archaeologists and funders. Deposit 
models can guide the investigation strategy at an individual site-scale, or, can make sense of larger datasets and disparate data, illustrate archaeological potential and provide a context for archaeological remains within a wider area. Therefore, a deposit modeling framework should be seen as the first step within the archaeological investigation, ideally initiated at desk-based assessment (DBA) stage, but something that can utilized throughout the life cycle of a project, providing a framework for pre-evaluation, excavation and post-excavation stages (Figure 2).

\section{Depositional and erosional environments, and the archaeological process}

All archaeological projects, whether undertaken in the commercial or research sector start with the same fundamental question: 'where are the archaeological sites and features located within the study area?' (Chapman, 2006, 10). In terms of archaeological site investigation strategies, a simplified but useful way to envisage the housing of archaeological resources is within two different types of environment: those where sediments are built up primarily through vertical and lateral accretion and hence archaeology is usually buried either as in-situ (primary) or secondary remains, and; those which erode, with archaeology located as primary remains directly on an eroded landform or preserved within cut features. Whilst this simple division has significant ramifications for archaeological preservation and site investigation strategies, the archaeological reality of this division is not always recognized.

The ability to identify archaeological sites located within generally erosive environments, which are geologically simple terrain units and landforms such as calcareous bedrock (the classic dryland context), or incised terrace surfaces, has witnessed a long history of archaeological development and investigation. A variety of airborne and terrestrial geoprospection techniques have been applied in such environments that can detect archaeological remains upon or close to the modern ground surface beneath shallow soils. For many decades vertical and oblique photography formed the backbone of airborne techniques (e.g. St Joseph, 1977), but in recent years lidar together with a 
suite of multispectral and hyperspectral remote sensing technologies have come to the fore (Challis and Howard, 2006; Rowlands and Sarris, 2007; Donneus et al., 2014). These airborne techniques have been allied with the development of ground-based prospection techniques such as gradiometer survey, earth resistance survey (Gaffney, 2008; David et al. 2008) and higher frequency ground-penetrating radar (Conyers, 2004). Within the terrestrial sphere, such geophysical techniques can be considered shallow prospection methodologies, with a limited depth penetration beneath the current ground surface (of $c .1 \mathrm{~m}$ ). Whilst they have an undoubted proven track record for detecting archaeological sites and features beneath shallow soils, cut into or on the surface of bedrock and erosional landforms, they cannot be used to detect archaeological remains greater than $1 \mathrm{~m}$ depth.

Deposit modeling then, is an approach that is applicable to these accreting depositional environments where sediments build up including urban areas, floodplains, inter-tidal and offshore submerged landscapes, and can aid prediction of where archaeological remains will occur, both spatially and temporally (Howard et al., 2008). In turn, this can inform the assessment of preservation potential both from a physical (Howard and Macklin, 1999) and geochemical perspective (Holden et al., 2006, De Beer and Seither, 2015, Malim et al., 2016). In this case, subsurface investigation strategies such as borehole logging and deep geophysical survey techniques (electromagnetic conductivity surveys, electrical resistivity surveys, cone penetration tests, lower frequency ground penetrating radar, sonar), analyze the stratigraphic and topographic variation of the sub-surface sediment architectures. The analysis of these datasets allows key geomorphological features to be modeled, such as paleochannels, buried gravel islands and elevated terraces (Passmore et al., 2002), and sub-surface interfaces, such as paleo-landsurfaces and paleosols (e.g. Chapman et al., 2009) and an appreciation of the depositional environments at the transition of drylands and wetlands in terrestrial contexts (e.g. French 2003, 7). Likewise, in marine contexts the available geophysical tools afford a significant depth penetration and hence capability for 
geoprospection to identify major landform assemblages and map paleo-landscapes (e.g. Gaffney et al. (eds) 2007; Ward 2015).

\section{Methods and approaches to deposit modeling}

In both terrestrial and marine environments, the methods used to investigate sub-surface stratigraphy can usefully be divided into techniques that sample and log the sediments directly (boreholes and gouge augering) and those that provide proxy measurements of the sub-surface sediment architecture and stratigraphy (geophysical survey methods). Such proxy measurements of the subsurface sequence, by phenomena such as conductivity or resistivity, require a two stage interpretative process. Firstly, the measured property has to be interpreted as a sediment type and landform (e.g. a gravel terrace, fine-grained sediment infilling a paleochannel), and these interpreted units have to be integrated within the wider deposit model. Conversely, with boreholes and gouge augering the sub-surface sediments are directly sampled and described, and these sediment units are placed into a wider stratigraphical framework for the study area.

In terrestrial environments, methods that have been applied to directly investigate vertically and laterally accreted sediment stacks to elucidate their archaeological potential include cone penetration testing (e.g. Bates et al., 2007), electromagnetic conductivity surveys (e.g. Verhagge et al., 2017), borehole surveys (e.g. Søe et al., 2017), electrical resistivity surveys (Ellwood et al., 1993) and ground penetrating radar surveys (Carey et al., 2006). In addition high resolution geomorphological mapping has been used to characterize landform assemblages at the current ground surface, which in turn, can be related to sub-surface landform architecture (Passmore et al., 2002). It is critical that the methods applied are sympathetic to the environments in question, such as the depth penetration of a given technique, or the amount of time required for capture data.

However, in all cases it is recommended that any geophysical survey of the sub-surface environment 
is complemented by the analysis of purposive boreholes (Figure 3). These boreholes, which might have been commissioned especially for the project or derived from older archived geological records (for example, the BGS Geolndex [http://www.bgs.ac.uk/geoindex/]) will allow refinement of the interpretation of the geophysical data sets and increase the confidence of the deposit model.

\section{Key issues with using deposit models}

As discussed, the current project brought together geoarchaeological deposit modeling practitioners from across England, to discuss the use and application of deposit modeling. Whilst the results are derived from the perspective of geoarchaeologists who work in England within primarily terrestrial and inter-tidal environments, the issues raised have applicability to any archaeologist undertaking deposit modeling.

\section{Archiving geoarchaeological data generated by deposit modeling}

Borehole information is the most commonly used data type for construction of deposit models, whether in commercial or research spheres. Part of the reason for this is the availability of preexisting geotechnical data, freely available via open-access repositories such as the National Geoscience Data Centre of the British Geological Survey(http://www.bgs.ac.uk/data/boreholescans/home.html). However, there is no mandatory requirement or, perhaps more significantly, culture, of geoarchaeological contractors and researchers working within the terrestrial sphere of archiving their records with the BGS or indeed other central repositories collating data relating to the historic (geological) environment, for example local authority Historic Environment Records (HERs) and the Archaeological Data Service (ADS). Consequently, failure to encourage geoarchaeologists to directly deposit their archives with established organizations and the lack of a bespoke central repository or database for geoarchaeological site investigations, including deposits models, means that many new studies are 
taken without, or with limited knowledge of previous investigations. Such a data repository could be digital, holding the paper records of the sediment logs for any boreholes from terrestrial archaeological projects and their $x y z$ location. In contrast, archaeologists working in offshore environments participate in the Marine Environmental and Information Data Network (MEDIN; http://www.oceannet.org/data submission/ads/), which provides a framework and conduit for the archiving of geoarchaeological datasets. Closer collaboration between terrestrial and marine workers could provide a starting point for discussion of a similar framework for land-based interventions. The lack of using such a central repository within terrestrial environments is problematic when geoarchaeologists move beyond the site scale, into looking at wider deposition patterns and processes, e.g. floodplain evolution and alluvial deposition across river reaches. Often, the value of an archaeological site can only be appreciated when it is witnessed in context of its wider depositional and archaeological environment, and if the data sets to construct such models are not accessible then such opportunities are lost or limited.

\section{Variable uptake of deposit modeling across the archaeological sector}

Beyond the marine environment, there has been a variable uptake of deposit modeling in terrestrial environments across the archaeological community, part of which is a consequence in differences in archaeological traditions between countries and regions. For example, the Netherlands have a tradition of using statistical predictive modeling techniques to investigate archaeological distributions across landscapes (Verhagen and Whitley, 2012), whilst in the UK, geoarchaeologists have developed approaches to infer the distribution of deep, accreted sediments and geomorphological categorization of study areas (e.g. Passmore et al., 2002). Within England, which has an established tradition of geoarchaeological practice, our project demonstrated that there has been a variable uptake in deposit modeling, with the majority of collated case studies coming from the south-east of the country. Part of this pattern can be explained by the distribution of individuals 
with key skill-sets and experience of deposit modeling and the presence of large archaeological consultancies with specialist geoarchaeological teams (with experience of deposit modeling), which in turn, helps to shape curatorial knowledge and inform the drafting of Written Schemes of Investigation and project briefs (e.g. Sidell et al., 2000, Bates \& Stafford, 2013); furthermore, the pace of development in the south-east where large-scale construction projects allied to major regeneration schemes are in progress, for example the area of Nines Elms of south London where the new American Embassy has been built, undoubtedly provide large budgets that allow innovation thinking (Stevenson, 2018).

\section{Integrating deposit models into archaeological excavation protocols}

Within archaeological projects there can be difficulty in integrating data derived from the geoarchaeological analysis of landforms and sedimentary sequences (within a deposit model), to the often narrower focus of the area of archaeological intervention. The degree of difficulty is a product of multiple factors, but the scale of the archaeological excavation and the complexity of the geomorphological evolution in the study area are critical factors. Interestingly, there has been very little specifically published on this subject, (although of course there are many archaeological publications that include a geoarchaeological landscape analysis), and this could be can be taken as an indication of limited integration between the two different fields of study. Related to this, many field archaeologists are often unaware of how the results from a deposit model feed into the recording of excavation data. In this situation it is essential for the constructor of the deposit model, usually a geoarchaeologist, to work directly alongside an excavation team in recording the contextual data; this provides an opportunity for the deposit model to be refined in the light of excavation data, and feed into the interpretation and recording of archaeological contexts. 
However, there are also more technical issues to integrating deposit modeling data further into archaeological excavation recording. Many of the sediment units recorded by geoarchaeologists are diachronous in their formation and can often form over long time periods, in some cases, thousands of years. These form the physical matrix that human activities are played out on and ultimately encased within, and are also the processes that bury and preserve these archaeological sites. Conversely, archaeologists are generally dealing with sediment deposits that have formed over much shorter time periods, such as pit cuts and fills. These two different timescales meet when the shorter-lived human contexts (events, e.g. a pit cut and fill sequence) interact within the longer forming diachronous sediment units (e.g. alluvium). Consequently, archaeologists and geoarchaeologists who are investigating the same site are approaching the investigation of sediment architecture and stratigraphy from opposing ends of a chronological spectrum. Given the longevity of the formation of some sediment units, they can often cause a stratigraphic inversion of the archaeological Harris Matrix, when they are modeled together, and this provides a barrier to a seamless integration of both data types. A hypothetical example of this would be a homogeneous thick alluvial unit, which is cut by a Neolithic pit in one part of a study area, but buries a Bronze Age house in another part of the study area, causing a stratigraphic inversion on a single site matrix.

Delegates at the deposit modeling workshop were unified in the need for geoarchaeologists and archaeologists to improve dialogue over the scales of the investigation they are working at and the methods that can be used to further integrate different recording techniques. Likewise, there was a perceived need for the promotion of the principles of geoarchaeology within UK degree programs and to consider not only how these relate to archaeological site formation, but how it be integrated into archaeological field excavation protocols.

4. Evaluation of techniques that have been applied to construct archaeological deposit models 
Although many techniques and methods had been utilized to construct deposit models, there has been little evaluation of the techniques within a deposit modeling context, and this lack of rigorous review leads to confusion. For example, curatorial archaeologists who attended the workshop commented that when drafting a project brief for a terrestrial development-led archaeological investigation, they could not specify which was the most appropriate deposit modeling methodology to be used since this information is currently not available, although within England (Historic England) regional science advisors can be consulted. Within an English context, since most deposit models are often constructed as part of a planning process, there are not sufficient resources to collect multiple data sets for comparative purposes, within a competitive tendering environment. Ultimately, this comparison of techniques must be driven from a research perspective, in order to compare the efficacy of different methods and approaches within different depositional environments.

\section{Lack of reporting of deposit models against archaeological realities}

Allied to the previous point, there has also been a lack of reporting of the results of deposit models against excavated (archaeological) realities. As previously discussed, although deposit models are being increasingly utilized within archaeological investigations, the success of such approaches is rarely reviewed in the context of subsequently excavated sites. The publication of a deposit model tested against evaluation trenching at a quarry site on the valley floor of the River Lugg Herefordshire (Carey et al. 2017) provides one of the few examples prior to the Historic England funded project; now, additional case studies are provided by individual chapters within the accompanying technical monograph (Carey et al., 2018). However, the papers described above should be seen as the starting point for a developing critique of deposit models, which includes a greater assessment of both successes but also failures, so that confidence can be placed in their use and methodologies further refined. 


\section{Outputs from deposit models}

Deposit models collect data using a range of methods, but also utilize a variety of softwares and techniques to interrogate and finally display these data sets. Illustrations that demonstrate the relationship of sedimentary units to each other can take the form of cross sections, analogous to more conventional archaeological sections drawings. Such sections can be drawn in bespoke software such as Rockworks or within illustration packages from hand drawn versions (e.g. Illustrator). Likewise, illustrations from the deposit models are often plan based showing modeled surfaces or thickness of deposits and these are often formed within a GIS based system (e.g. ARCGIS) or bespoke modeling software (e.g. Rockworks).

A section demonstrates a two dimensional representation of sediment stratigraphy over the site and can be used to represent the thickness of any unit represented in the section (Figure 4); comparatively, a surface produced within a GIS based system models the interfaces between two or more surfaces, e.g. the top of the river terrace gravel, and as such define the surface or interface of a sediment body as height below ground level or as an interpolated unit thickness (Figure 5). However, both methods are effectively a 2D reconstruction of sub-surface environments.

A general consensus reached during the workshop was for any reporting on the deposit model must include plans and identify key surfaces but also to provide a representative cross section. Key sediment units require definition and description and are essential in the reporting stage, with the data included as an appendix. This allows not only the graphical representations to be viewed, but also the interpretation of the key surfaces and how they have been derived from the original data, and the results to be reproduced if desired.

\section{The future of deposit modeling}


It is clear that deposit models are a useful part of the archaeological process and an essential tool of the archaeologist. With any archaeological project that is investigating complex sedimentary environments, a deposit model is an essential first step in the project that will allow resources to be focused on the areas of highest archaeological potential. In the post-excavation stages they provide the wider landscape narrative of the site and its evolution, and in this sense provide the vehicle for the context and framework for the whole archaeological process. Consequently, a deposit model should ideally be one of the first considerations in any archaeological project.

With a deposit model in place archaeological resources can be directed to where they are most needed. Without a deposit model, designing evaluation trenching strategies is problematic and can often dig 'blind', in order to test if archaeology is present in the study area. The percentage of the land take used for the evaluation strategy is often $5 \%$ within a UK planning process context, based on simulation approaches of remodeling existing archaeological data sets (Hey and Lacey 2001). In the archaeological world, where money and resources are often limited, evaluation trenching is best used to evaluate what archaeology is present in areas of significant potential, rather than testing whether any archaeological remains are present (Carey et al., 2017). Deposit modeling allows a first approximation of archaeological distribution to be tested and in doing so reduces the burden of evaluation trenching and allows a greater focus on mitigation excavation. This not only saves time and money but it also increases the archaeological product from any project. With deposit modeling increasing in its application and scale, there is a further need to assess the methods used in archaeological deposit modeling, to investigate the successes or otherwise of the practices undertaken.

With continuing advances in archaeological scientific methods being reported in journals such as 'Journal of Archaeological Science' and 'Geoarchaeology', it is clear that there are increasingly sophisticated suite of techniques that are being used to investigate the richness of the archaeological record. Geoarchaeological approaches are particularly well-suited to this task, as 
techniques can be targeted to different spatial and temporal scales, providing an integrated or nested analysis of the archaeological remains and its environs. These techniques are working from the macro-scale (landscapes), through to the site scale (in-situ measurements and analysis) through to the micro-scale (micromorphology, artefact analysis, etc). In this sense deposit modeling is an approach that we consider to be integral to allowing these different scales of investigation to be drawn into a more seamless whole, and provide an overall context for the investigation of the archaeological record within archaeologically-rich, but geomorphologically complex, deep sedimentary systems.

\section{Acknowledgements}

The concept of this paper and much of its content is derived from the Historic England sponsored project awarded to the authors entitled 'Deposit modeling for archaeological projects: a review of good practice' (Project Number 7257); the authors gratefully acknowledge the support of Historic England throughout the process and in particular, Dr Jane Sidell and Hannah Fluck as 'critical friends'. The authors also wish to thank all of the archaeologists who attended the project workshop in London (June 2016) and contributed their views and experiences to the discussions. Finally, the authors acknowledge the comments of Dr Andrew Bicket and two other anonymous referees whose reviews improve the revised manuscript.

\section{Bibliography}

Ames, C. J. H. and Cordova, C. E. 2015. Middle and Late Pleistocene Landscape Evolution at the Druze Marsh Site in Northeast Jordan: Implications for Population Continuity and Hominin Dispersal. Geoarchaeology, 30:4, pp. $307-329$. 
Amato, V., Ciarcia, S., Rossi, A. and Santoriello, A. 2018. The urban geoarchaeology of Benevento, southern Italy: Evaluating archaeological potential. Geoarchaeology, 33, pp. 100-111.

Ayala, G., Wainwright, J., Walker, J., Hodara, R., Lloyd, J. M., Leng, M. Doherty, C. 2017. Palaeoenvironmental reconstruction of the alluvial landscape of Neolithic Çatalhöyük, central southern Turkey: the implications for early agriculture and responses to environmental change. Journal of Archaeological Science, 87, pp. 30-43.

Bailey, G. N., Devès, M. H., Inglis, R. H., Meredith-Williams, M. G., Momber, G., Sakellariou, D., Sinclair, A. G. M., Rousakis, G., Al Ghamdi, S. and Alsharekh, A. M. 2015. Blue Arabia: Palaeolithic and underwater survey in SW Saudi Arabia and the role of coasts in Pleistocene dispersal. Quaternary International, 282, pp. 42-57.

Barker, P. 1993. Techniques of archaeological excavation. Routledge: London.

Bates, M. and Stafford, E. 2013. Thames Holocene: A geoarchaeological approach to the investigation of the river floodplain for High Speed 1, 1994-2003. Oxford Wessex Archaeology monograph, Oxbow: Oxford.

Bates, M. R., Bates, C. and Whittaker, J. E. 2007. Mixed method approaches to the investigation and mapping of buried Quaternary deposits: examples from southern England. Archaeological Prospection, 14, pp. $104-129$.

Bates, M. R. and Bates, C. R. 2000. Multidisciplinary approaches to geoarchaeological evaluation of deeply stratified sedimentary sequences: examples from Pleistocene and Holocene deposits in Southern England, United Kingdom. Journal of Archaeological Science, 27, pp. 845 - 858.

Bicket, A. and Tizzard, I. 2015. A review of the submerged prehistory and palaeolandscapes of the British Isles. Proceedings of the Geologists' Association, 126 (6), pp. 643-663. 
Brown, A. G., Bassel, L. S. and Toms, P. S. 2015. A stacked Late Quaternary fluvio-periglacial sequence from the Axe valley, southern England with implications for landscape evolution and Palaeolithic archaeology. Quaternary Science Reviews, 116, pp. 106-121

Brown, A.G., Hatton, J., Pearson, L. Roseff, R. and Jackson, R. 2005. The Severn-Wye revisited: Lateglacial-Holocene floodplain palaeoenvironments in the Lugg Valley, in Smith, D.N., Brickley, M.B. \& Smith, W. (eds). Fertile Ground: Papers in Honour of Susan Limbrey. Symposia of the Association for Environmental Archaeology no 22, pp. 16-29. Oxbow Books: Oxford.

Burton, E., Corcoran, J., Halsey, C., Spurr, G. and Burton, P. J. 2011. Mapping Past Landscapes in the Lower Lea Valley. MOLAS: London.

Canti, M., Corcoran, J., Ayala, G., Heathcote, J., Usai, R. and Sidell, J. 2015. Geoarchaeology - Using Earth Sciences to Understand the Archaeological Record. Historic England: London.

Carey, C., Corcoran, J., Howard, A., Knight D. and Heathcote, J. (eds). 2018. Deposit modeling for archaeological projects. Short Run Press: Exeter.

Carey, C. J. and Knight, D. 2018. Grove Farm, Nottingham: modeling the alluvial sequence of the Middle Trent Valley, in C Carey, J Corcoran, A Howard, D Knight and J Heathcote, (eds), Deposit modeling for archaeological projects, pp. 69-84 Short Run Press: Exeter.

Carey, C., Howard, A., Jackson, R. and Brown, A. 2017. Using geoarchaeological deposit modeling as a framework for archaeological evaluation and mitigation in alluvial environments. Journal of Archaeological Science: Reports, 11. pp. 658-673.

Carey, C. J., Brown, A. G., Challis, K. C., Howard, A. H. and Cooper, I. 2006. Predictive modeling of multiperiod geoarchaeological resources at a river confluence: a case study from the Trent-Soar, UK. Archaeological Prospection, 13:4, pp. 241-250. 
Challis, K. and Howard, A. J. 2006. A review of trends within archaeological remote sensing in alluvial environments. Archaeological Prospection, 13, pp. $231-240$.

Champness, C. 2018. Bexhill to Hastings link road, East Sussex: a geoarchaeological deposit model on the Comve Haven and surrounding valley sequences, in, C Carey, J Corcoran, A Howard, D Knight and J Heathcote, (eds), Deposit modeling for archaeological projects, pp. 53-66. Short Run Press: Exeter

Chapman, H. 2006. Landscape archaeology and GIS. Stroud: Tempus.

Chapman, H.P. and Gearey, B.R. 2013. Modeling Archaeology and Palaeoenvironments in Wetlands. Oxford: Oxbow Books.

Chapman, H., Adcock, J. and Gater, J. 2009. An approach to mapping buried prehistoric palaeosols of the Atlantic seaboard in Northwest Europe using GPS, geoarchaeology and GIS and the implications for heritage management. Journal of archaeological Science, 36, pp. $2308-2313$.

Conyers, L. B. 2004. Ground penetrating radar for archaeologists. California: Left Coast Press.

Cowrie, 2011. Offshore Geotechnical Investigations and Historic Environment Analysis: Guidance for the Renewable Energy Sector Final Report January 2011. Cowrie.

David, A., Linford, N. and Linford, P. 2008. Geophysical survey in archaeological field evaluation. Swindon: English Heritage.

De Beer, H. and Seither, A. 2015. Groundwater balance, in J Rytter and I Schonhowdl (eds), Monitoring, Mitigation, Management: The Groundwater Project-Safeguarding the World Heritage Site of Bryggen in Bergen. Oslo: Riksantikvaren

Doneus, M., Verhoeven, G., Atzbergerd, C., Wess, M. and Ruš, M. 2014. New ways to extract archaeological information from hyperspectral pixels. Journal of Archaeological Science, 52, pp. 8496. 
Ellwood, B. B., Harrold, F. B., Petruso, K. M. and Korkuti, M. 1993. Electrical resistivity surveys as indicators of site potential: Examples from a rock shelter in Southwestern France and a cave in Southern Albania, Geoarchaeology, 8:3, pp. 217 - 227.

French C. 2003. Geoarchaeology in Action. Chapter 7 The Fengate Shore, Lower Nene Valley and Flag Fen basin, Cambridgeshire, England. Routledge: London.

Gaffney, C. F. 2008. Detecting trends in prospecting for the past: fifty years of geophysical survey. Archaeometry, 50, pp. 313-336.

Gaffney, V., Thomsen, K. and Fitch, S. (eds) 2007. Mapping Doggerland: The Mesolithic Landscapes of the Southern North Sea. Archaeopress: Oxford.

Hey, G. and Lacey, M. 2001. Evaluation of archaeological decision-making processes and sampling strategies. Kent County Council: Kent.

Holden, J., West, L. J., Howard, A. J., Maxfield, E., Panter, I. and Oxley, J. 2006. Hydrological controls of in situ preservation of waterlogged archaeological deposits. Earth-Science Reviews, 78:1-2, pp. 59-83.

Howard, A., Brown, A., Carey, C., Challis, K., Cooper, L., Kincey, M. and Toms, P. 2008. Archaeological resource modeling in temperate river valleys: a case study from the Trent Valley, UK. Antiquity, 82:318, pp. 1040-1054.

Howard, A.J., Macklin, M.G., Passmore, D.G. (Eds). 2003. Alluvial Archaeology in Europe. Balkema: Abingdon.

Howard, A.J. and Macklin, M.G. 1999. A generic geomorphological approach to archaeological interpretation and prospection in British river valleys: a guide for archaeologists investigating Holocene landscapes. Antiquity, 73: 281, pp. 527-541. 
Krawiec, K. 2018. Medmerry managed realignment scheme, West Sussex: a Holocene deposit model of a coastal environment, in C Carey, J Corcoran, A Howard, D Knight and J Heathcote, (eds), Deposit modeling for archaeological projects, pp. 149-158. Short Run Press: Exeter.

Malim, T., Swain, M., and Panter. I. 2016. Monitoring and Management options in the preservation of urban waterlogged deposits, Nantwich, UK. Conservation and Management of Archaeological Sites, 18 (1-3), pp. 139-55.

Mozzi, P., Ferrarese, F., Zangrando, D., Gamba, M., Vigoni, A., Sainati, C., Fontana, A., Ninfo, A., Piovan, S., Rossato, S. and Veronese, F. 2018 The modeling of archaeological and geomorphic surfaces in a multi-stratified urban site in Padua, Italy. Geoarchaeology, 33, pp. 67-84

Nwankwo, C. N., Anyanwu, J., and Ugwu, S. A. 2014. Integration of seismic and well log data for petrop[hysical modeling of sandstone hydrocarbon reservoir in Niger Delta. Scientia Africana, 13 (1), pp. 186-199.

Neal, C. 2014. The potential of integrated urban deposit modeling as a cultural heritage planning tool. Planning practice and research, 29:3, pp. $256-257$.

Passmore, D.G., Waddington, C. and van der Schriek, T., 2006. Enhancing the evaluation and management of river valley archaeology: geoarchaeology, in the Till-Tweed catchment, northern England. Archaeological Prospection, 13, pp. 269-281.

Passmore, D. G., Waddington, C. and Houghton, S. J. 2002. Geoarchaeology of the Millfield basin, Norther England; towards an integrated archaeological prospection, research and management framework. Archaeological Prospection, 9, pp. $71-91$.

Pastre, J.-F., Leroyer, C., Limondin-Lozouet, P., Antoine, P., Chaussé, C., Gauthier, A., Granai, S., Le Jeune, Y., and Wuscher, P. 2014. The Holocene evolution of the Patis Basin (France). Contribution of 
geoecology and geoarchaeology of floodplains, in Arnaud-Fassetta, G. and Carcaud, N. (Eds.) 2014. French Geoarchaeology in the 21st Century. CNRS Editions, Paris, pp. 87-104.

Price, S., Ford, J., Cooper, A., and Neal, C. 2011. Humans as major geological and geomorphological agents in the Anthropocene: The significance of artificial ground in Great Britain. Philosophical Transactions of the Royal Society A, 369, pp. 1056-1084.

Renfrew, A. C. 1976. Introduction, in Davidson, D. A., and M. L. Shackley (eds), Geoarchaeology. Geoarchaeology: Earth Science and the Past. Duckworth: London.

Rowlands, A. and Sarris, A. 2007. Detection of exposed and subsurface archaeological remains using multi-sensor remote sensing. Journal of Archaeological Science, 34, pp. 795-803.

Schott, A. M. 2017. Site Formation Processes and Depositional Environment of a Fine-Grained Alluvial Floodplain at La Playa Archaeology Site, Sonora, Mexico. Geoarchaeology, 32:2, pp. 283 301.

Sidell, J. Wilkinson, K., Scaife, R. and Cameron, N. 2000. The Holocene Evolution of the London Thames. Museum of London Archaeology Monograph 5, London.

Søe, N. E., Odgaard, V. B., Hertz, E. and Holst, M. K. 2017. Geomorphological setting of a sacred landscape: Iron age post battle deposition of human remains at Alken Enge, Denmark.

Geoarchaeology, $32(5)$, pp. $521-533$.

Stevenson, M. 2018. A planning development management perspective: deposit modeling in south London, in C Carey, J Corcoran, A Howard, D Knight and J Heathcote, (eds), Deposit modeling for archaeological projects, pp. 205-218. Short Run Press: Exeter.

St Joseph, J. K. S. 1977. Uses of air photography. A \& C Black Publishers Ltd: New York. 
Verhagge, J., Saey, T., Van Miervenne, M. and Missiaen, T. 2017. Reconstructing Early Neolithic Paleogeography: EMI-Based Subsurface Modeling and Chronological Modeling of Holocene Peat below the Lower Scheldt Floodplain in NW Belgium. Geoarchaeology, 32 (2), pp. 159-176.

Verhagen, P. and Whitley, T. G. 2012. Integrating archaeological theory and predictive modeling: a live report from the scene. Journal of Archaeological Method and Theory, 19, pp. 49-100.

Ward, I. 2015. Depositional Context as the Foundation to Determining the Palaeolithic and Mesolithic Archaeological Potential of Offshore Wind Farm Areas in the Southern North Sea. Conservation and Management of Archaeological Sites, 16 (3), pp. 212-235. 
Figure 1: An example of a deposit model, showing below ground surface sediment deposits of a River Valley, modeled as pseudo 3D solid units using Rockworks. 
Search for pre-exisiting geotechnical/borehole data within the study area

Construct deposit model, consider purposive boreholes, deeper geophysical survey methods - Define key geomorphological and sediment units, and key surfaces

- If areas of shallow deposits are discovered consider shallow geophysical methods for determination of archaeological structures, e.g. gradiometry

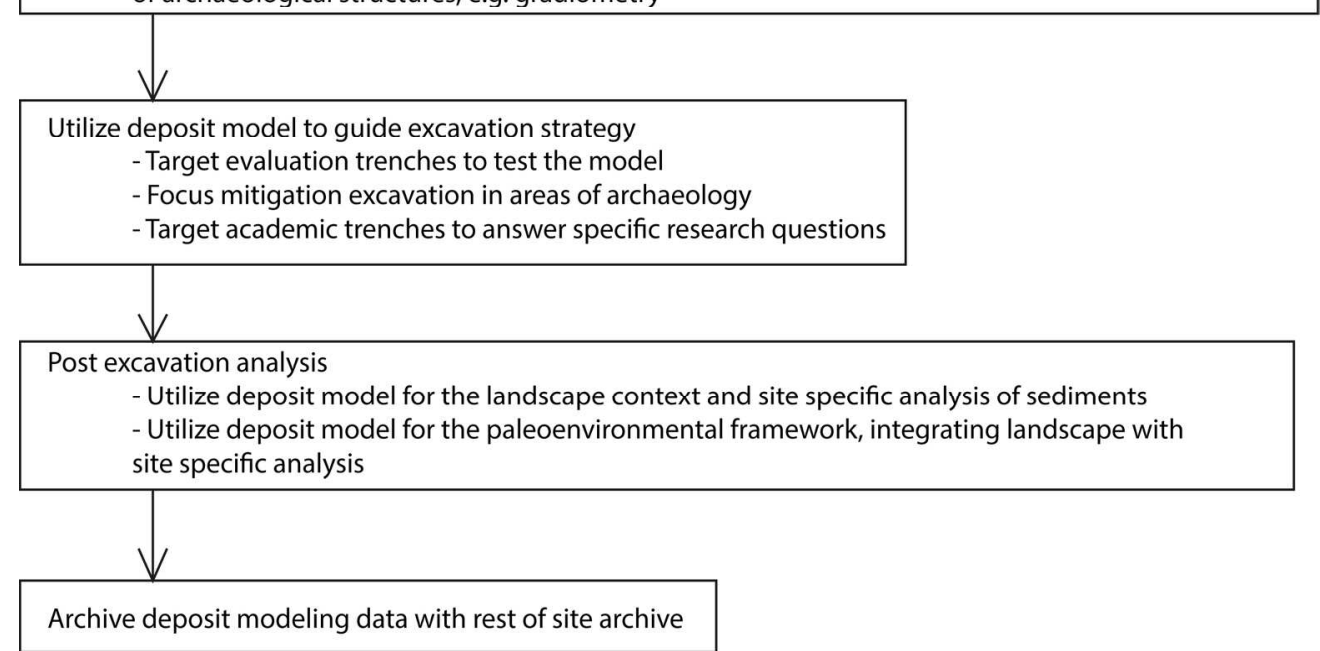

Figure 2: Position of deposit modeling within the archaeological process.

$174 \times 156 \mathrm{~mm}(300 \times 300 \mathrm{DPI})$ 
Figure 3: Chertsey Abbey Meads survey on the River Thames floodplain, showing electrical conductivity data collected using an EM31, and location of the purposive boreholes conducted for the deposit model, to ground truth the conductivity variations evident.

$$
210 \times 148 \mathrm{~mm}(300 \times 300 \mathrm{DPI})
$$


Figure 4: Two cross sections from deposit models. Top: Heslington East Deposit Model, York, UK, modeling a set of complex Holocene deposits above Pleistocene sands, derived from powered terrier cores and Bottom: Lanacombe Deposit Model Exmoor, UK, mapping a paleosol and Pleistocene Head deposits underneath the current peat deposits, derived from gouge core data. 
Figure 5: Deposit model at Grove Farm Nottingham, located on the River Trent floodplain showing, Top: Upper surface of the modeled River Terrace Sands and Gravels showing a lower area centre/right of surface (paleochannel), and bottom: the upper surface of fine grained, organic rich, paleochannel sediments infilling this depression in the River Terrace Sands and Gravels.

$$
297 \times 420 \mathrm{~mm}(300 \times 300 \mathrm{DPI})
$$

